\title{
Intensifying bare fallow strategies to control Elymus repens in organic soils
}

\author{
${ }^{1}$ Timo Lötjönen and ${ }^{2} J u k k a$ Salonen \\ ${ }^{1}$ Natural Resources Institute Finland (Luke), Tutkimusasemantie 15, FI-92400 Ruukki, Finland \\ ${ }^{2}$ Natural Resources Institute Finland (Luke), Tietotie 4, Fl-31600 Jokioinen, Finland \\ email: timo.lotjonen@luke.fi
}

\begin{abstract}
Perennial weeds are an increasing challenge in organic farming in the Nordic countries. The aim of this study was to compare different tillage methods in the control of Elymus repens by using two intensified bare fallow strategies. Two field experiments consisted of three ploughing methods and seven fallow methods. The experiments were carried out in organic soils in Central Finland. The methods applied in the brief fallow before cereal sowing (exp. 1) were not effective enough against $E$. repens. Due to wet weather conditions in the spring the fallow period was limited to two weeks in both years, which did not seem to be enough time. In the late summer fallow after ley (exp. 2), the Kvick-Finn weed-cultivator destroyed E. repens very effectively; on average $5 \%$ of $E$. repens remained alive in the barley crop in the autumn of the following year. After use of ordinary cultivators $10 \%$ of $E$. repens remained alive, after use of the spade harrow $25 \%$ and after frequent mowing over $50 \%$ remained alive, respectively. As a result of effective $E$. repens control, barley yield was about $1000 \mathrm{~kg} \mathrm{ha}^{-1}$ higher than without any fallow. In conclusion, effective control of $E$. repens is achieved with proper machinery and repeated treatments at the optimal time.
\end{abstract}

Key words: fallowing, Kvick-Finn, mechanical control, organic farming, perennial weed, tillage

\section{Introduction}

Perennial weeds are recognised as an increasing challenge in organic farming in the Nordic countries (Salonen et al. 2011, Brandsaeter et al. 2012, Melander et al. 2012). In Finland, Elymus repens (L.) Gould is the most abundant perennial weed, but also Cirsium arvense L. and Sonchus arvensis L. are becoming more common in organic farming (Riesinger 2010, Salonen et al. 2011). Perennial weeds can decrease remarkably amounts of yield in organic cereals and protein crops and hamper harvest operations (Melander 1994, Graglia et al. 2006). The development of non-chemical perennial weed control methods is also essential in conventional farming, since there is an universal need to decrease the use of glyphosate and other herbicides (Melander et al. 2013a).

In organic farming weeds are controlled by a combination of preventive, cultural and direct control methods. Including frequently mowed perennial leys in the crop rotation helps to control $C$. arvense and S. arvensis, but E. repens often tends to proliferate in old leys (Dock Gustavsson 1994, Graglia et al. 2006, Vanhala et al. 2006). However, most organic farms without livestock cannot utilize the yield of perennial leys, so the crop sequence mainly consists of annual crops. This often leads to increasing problems with perennial weeds. Undersown cover crops and post-harvest mowing after the main crop harvest may help to control perennial weeds (Aronsson et al. 2015, Ringselle et al. 2015a), but cover crops have not always been effective (Brandsaeter et al. 2012).

Traditional bare fallow, which lasts the whole summer, is known to be rather effective against perennial weeds, but it is expensive (one year without crop and requires much work and fuel), it can be harmful to the soil structure, and it can lead to nutrient leaching (Bond \& Grundy 2001). There is a need for intensified strategies to be used in fallowing. Intensifying here means achieving a better effect against weeds, less working hours and shorter fallowing time compared to traditional bare fallow.

In principle, bare fallow can be based on four mechanisms: 1) lifting the roots or rhizomes of perennial weeds to the soil surface so that the sun and wind will desiccate them, 2) conducting tillage at compensation points, i.e. applying an exhaustion strategy, 3) cutting weed roots into small pieces and burying the pieces deep in soil or 4) lifting the roots to the soil surface and removing them (Håkansson 1995, Dock Gustavsson 1997, Melander et al. 2013b). In practice, all strategies can be used in the same field depending, for example, on weather conditions and cropping sequences. Equipment that would perfectly execute strategies 1 and 4 is challenging to design (Kristensen et al. 2010). In many situations, the best weed control result can be achieved when strategy 2 is applied. Compensation point (i.e. time, when dry matter weight of roots is at a minimum) have shown to be 3-4 leaves for E. repens (Håkansson 1967). 
In practice, bare fallow can be implemented using at least five different strategies (estimated duration of fallow period at northern latitudes in parenthesis): 1) brief fallow in spring before crop sowing (2-4 weeks), 2) fallowing during May-June followed by sowing green manure crops (2 months), 3) harvest one silage yield and fallowing after that (late summer fallow) (3 months), 4) bare fallowing the whole summer (5 months) and 5) stubble cultivation after cereal harvest (1-2 months) (Håkansson 1995).

For the tillage of bare fallow, many types of machinery can be used, for example S-tine harrows, tined cultivators, disc harrows/cultivators, rotary cultivators, power harrows and rotary spade harrows (Kristensen et al. 2010, Melander et al. 2012). The Kvick-Finn weed-cultivator (KF-cultivator) is a fairly new type of machinery, specially designed to lift roots of perennial weeds up to the soil surface and thus, increase the efficacy of bare fallow against vegetatively propagating weed species.

Minimal studies have been conducted on the weed control efficacy of the Kvick-Finn or preceding Kvick-Upp cultivator. Jacobsson (2006) examined Kvick-Upp as a stubble cultivation tool after cereal harvest in Sweden. E. repens had decreased more than $80 \%$, when two cultivations were performed in autumn and one in spring followed by spring ploughing. Without stubble cultivation, in clay soils, spring ploughing controlled E. repens slightly better than autumn ploughing, and in lighter soils the opposite was noted.

In Sweden, Ringselle et al. (2015b) managed to control E. repens successfully in loamy soils by means of 1-2 stubble cultivations with a tined cultivator, which was followed by autumn ploughing. Also studies made in Norway and Denmark managed to significantly reduce perennial weeds by means of stubble cultivation (Brandsaeter et al. 2012, Melander et al. 2012). In Finland, stubble cultivation could also be beneficial for the control of perennial weeds if the autumn season is dry and warm (Vanhala et al. 2006). However, very often autumn is too short and wet for repeated tillage to achieve reliable weed control after cereal harvest.

Therefore, we decided to focus on strategies 1 and 3 described above. The main objective was to find out the most effective tillage methods in the control of E. repens in brief fallow in spring before cereal sowing (experiment 1) and in late summer fallow when old ley is broken up (experiment 2). Previous crops had been cereals in experiment 1 and ley in experiment 2 . We chose three ploughing methods and three non-inverse tillage methods for experiment 1 and five fallow methods for experiment 2 . We decided to concentrate on $E$. repens, since it is the most abundant perennial weed in organic farming in Finland.

\section{Material and methods}

Two experiments were conducted at the MTT Ruukki Research Station in Central Finland $\left(64^{\circ} 41, \mathrm{~N} ; 25^{\circ} 05, \mathrm{E}\right)$ during the period 2012-2014. Experiment 1 (Brief fallow exp.) was located in the same fixed place for two years. Experiment 2 (Late summer fallow exp.) was transferred to a new location for both years, since the treatments destroyed the ley during the first summer. The fields were not certified organic, but no pesticides or synthetic fertilizers were used during the study. The studies were carried out in peat/organic soils, in which E. repens seems to proliferate extremely fast.

The basic idea of the KF-cultivator was developed in Denmark at the beginning of 2000, but currently the machine is being further developed and manufactured by a Finnish company. Goosefoot tines loosen the soil and after that a PTO-driven rotor throws soil and weed roots/ rhizomes into the air (Suppl. Figs. 1 and 2). Since weed roots are lighter than soil, roots will settle on the soil surface, where they are desiccated by the sun and wind. If the weather is not dry, the roots use their energy when they begin to grow again. The manufacturer claims that repeated treatments with the KF-cultivator near the compensation point can destroy perennial weeds also during wet conditions, but it takes a longer time to achieve sufficient results than during dry periods (http://www.ekotjanst.fi/).

\section{Experiment 1}

In experiment 1, the objective was to compare autumn and spring ploughing to minimum tillage and to the KF-cultivator by measuring their effects on E. repens growth and barley yield (Table 1). In the first year, autumn ploughing was not possible, so it was replaced by spring ploughing. Furthermore, we wanted to gain knowledge about the benefits of trashboards and skimmers installed on ploughs (Suppl. Figs. 3 and 4). These implements are used to drop topsoil to the bottom of the furrow. This is assumed to delay emergence of weeds through furrow joints. 
In experiment 1, the soil type was carex peat ( $\mathrm{pH}$ 5.6). Spring barley had been cultivated in that location in the period 2009-2011. Glyphosate was applied previously in autumn 2010 in order to control E. repens. In spring 20122013 the experimental area was cultivated using treatments described in Table 1 (Suppl. Figs. 1-6). After that the area was fertilised with beef cattle slurry and drilled with spring barley.

Ploughing depth was $22-25 \mathrm{~cm}$ and driving speed $5-8 \mathrm{~km} \mathrm{~h}^{-1}$. The goosefoot tines of the KF-cultivator were set to a depth of $10-12 \mathrm{~cm}$ and driving speed was $4-5 \mathrm{~km} \mathrm{~h}^{-1}$.

The size of experimental plots was $6 \times 30 \mathrm{~m}$, to allow for the use of machinery typical on Finnish farms. The number of $E$. repens shoots was counted from both ends of the plots at the beginning of experiment 1 (on 15th May 2012) by using a $2 \times 0.25 \mathrm{~m}^{2}$ frame. In autumn 2012, experimental plots were harvested and a sample corresponding to a $1 \mathrm{~m}^{2}$ area was taken from the swath $\left(2 \times 0.5 \mathrm{~m}^{2}\right)$. In autumn 2013, crop samples were taken at both ends of the plots by using a $2 \times 0.25 \mathrm{~m}^{2}$ frame before the barley harvest. The crop samples were cut to $2-4 \mathrm{~cm}$ stubble height by electric scissors. The samples were separated into barley, E. repens and other weeds in both years. Dry weight of weeds was measured after oven-drying $\left(+105^{\circ} \mathrm{C}, 24 \mathrm{~h}\right)$. Barley was harvested by a Wintersteiger-plot combine harvester. Barley hectolitre weights were measured by a chondrometer.

Table 1. Treatments and other farming operations in experiment 1. Treatments were repeated in the same fixed place in 2012 and 2013.

\begin{tabular}{|c|c|c|c|c|c|c|}
\hline \multicolumn{7}{|c|}{ Treatments } \\
\hline \multirow{3}{*}{ Autumn 2011} & $\begin{array}{l}\text { 1) Spring } \\
\text { or autumn } \\
\text { ploughing with } \\
\text { trashboards }\end{array}$ & $\begin{array}{l}\text { 2) Spring } \\
\text { ploughing, no } \\
\text { implements }\end{array}$ & $\begin{array}{l}\text { 3) Spring ploughing } \\
\text { with skimmers }\end{array}$ & $\begin{array}{l}\text { 4) Spring cultivation } \\
\text { with discs or rotary } \\
\text { spade harrow } \\
\text { (3-4 times) }\end{array}$ & $\begin{array}{l}\text { 5) Spring } \\
\text { cultivation } \\
\text { with KF- } \\
\text { cultivator } \\
\text { ( } 2 \text { times) }\end{array}$ & $\begin{array}{l}\text { 6) Spring } \\
\text { cultivation with } \\
\text { KF-cultivator } \\
\text { (2-3 times) }\end{array}$ \\
\hline & \multicolumn{6}{|c|}{ No cultivations in autumn 2011. Preceding crop in 2011: spring barley. } \\
\hline & $\begin{array}{l}\text { Spring ploughing } \\
24 \text { May }\end{array}$ & $\begin{array}{l}\text { Spring ploughing } \\
24 \text { May }\end{array}$ & $\begin{array}{l}\text { Spring ploughing } \\
24 \text { May }\end{array}$ & $\begin{array}{l}\text { Disc harrow } \\
4 \text { times, } \\
\text { 24-30 May }\end{array}$ & $\begin{array}{c}\text { KF-cultivator } \\
2 \text { times, } \\
\text { 24-30 May }\end{array}$ & $\begin{array}{l}\text { KF-cultivator, } \\
3 \text { times } \\
24 \text { May-6 June }\end{array}$ \\
\hline \multirow[t]{4}{*}{ Spring 2012} & \multicolumn{6}{|l|}{ Seedbed harrowing } \\
\hline & \multicolumn{6}{|c|}{ Beef cattle slurry 20 ton ha-1 ( $44 \mathrm{~kg}^{-}$soluble $\mathrm{N} \mathrm{ha}^{-1}$ ) and harrowing, 7 June } \\
\hline & \multicolumn{6}{|c|}{ Sowing spring barley (var. "Brage") 500 seeds $\mathrm{m}^{-2}, 8$ June } \\
\hline & Barley harvest and & Need samples, $18 \mathrm{~S}$ & & & & \\
\hline \multirow[t]{2}{*}{ Autumn 2012} & $\begin{array}{c}\text { Autumn } \\
\text { ploughing, } 11 \text { Oct }\end{array}$ & & No cultivations ir & autumn 2012 & & $\begin{array}{l}\text { Autumn } \\
\text { ploughing, } \\
11 \text { Oct }\end{array}$ \\
\hline & & $\begin{array}{l}\text { Spring ploughing } \\
31 \text { May }\end{array}$ & $\begin{array}{l}\text { Spring ploughing } \\
31 \text { May }\end{array}$ & $\begin{array}{l}\text { Rotary spade } \\
\text { harrow, } 3 \text { times, } \\
20 \text { May-3 June }\end{array}$ & $\begin{array}{l}\text { KF-cultivator } \\
2 \text { times } \\
\text { 21-27 May }\end{array}$ & $\begin{array}{l}\text { KF-cultivator } \\
2 \text { times } \\
\text { 21-27 May }\end{array}$ \\
\hline \multirow[t]{3}{*}{ Spring 2013} & \multicolumn{6}{|l|}{ Seedbed harrowing } \\
\hline & \multicolumn{6}{|c|}{ Beef cattle slurry 18 ton ha-1 ( $40 \mathrm{~kg}$ soluble $\mathrm{N} \mathrm{ha}^{-1}$ ) and harrowing, 3 June } \\
\hline & \multicolumn{6}{|c|}{ Sowing spring barley (var. "Brage") 500 seeds m², 3 June } \\
\hline Autumn 2013 & \multicolumn{6}{|c|}{$\begin{array}{l}\text { Weed samples, } 3 \text { Sep } \\
\text { Barley harvest, } 9 \text { Sep }\end{array}$} \\
\hline
\end{tabular}

\section{Experiment 2}

In experiment 2, the aim was to compare the tined cultivator, rotary spade harrow and KF-cultivator in late summer fallow, when old ley is broken up mechanically (Tables 2 and 3 ). It is known that in old leys rhizomes of $E$. repens grow quite near the soil surface and it is possible to cut rhizomes by frequent shallow cultivations (Håkansson 1995). Usually it is not reasonable to plough the ley in the beginning of fallowing, since ploughing will bury the rhizomes too deep to be controlled mechanically.

In experiment 2, the soil type was carex peat ( $\mathrm{pH}$ 5.6) in 2012-2013 and coarse sand with high organic content (pH 5.8) in 2013-2014. The experimental field had been used as silage ley (timothy-meadow fescue) for three years when the experiment was started in 2012. In 2012-2013 and 2013-2014 the experiments were located in a different part of the same field.

One silage yield was harvested in June in both years from experimental areas, after which the remaining ley was cultivated using different methods. In 2012, the beginning of cultivations was delayed until mid-July due to rainy weather. In 2013, cultivations were started already in June (Tables 2 and 3). Cultivations were carried out every 
2-3 weeks (near the compensation point of E. repens) until the beginning of September or October, depending on weather conditions. In the first year of the experiment one pass was made with the KF-cultivator in the following spring before barley sowing, but in the second year, spring cultivation was not carried out. All experimental plots were ploughed in the following spring, fertilized with beef cattle slurry and drilled with spring barley.

There were two different treatments with the KF-cultivator: In treatment 2 the first cultivation was done with the rotary spade harrow to ensure that the KF-cultivator can break the surface of the ley. Treatment 3 was started directly with the KF-cultivator, which succeeded well, as the soil was soft enough. The rotary spade harrow that was used in the experiments was an old Wärtsila Hankmo (3.2 m wide) with six spade axels (Suppl. Fig. 6). The weight of the machine was not enough to break the ley surface with one pass and this was compensated for by working the plots twice during same day. Unfortunately, it was not possible to get a new, heavy and long-bladed rotary spade harrow to use for the experiments. The SMS-tined cultivator (treatment 4) had spring tines with narrow blades in the first year and rigid tines with goosefoot blades in the second year (Suppl. Figs. 7 and 8 ).

Table 2. Treatments and other farming operations in experiment 2 in 2012-2013

\begin{tabular}{|c|c|c|c|c|c|c|}
\hline \multicolumn{7}{|c|}{ Treatments } \\
\hline \multirow{4}{*}{ Summer 2012} & $\begin{array}{l}\text { 1) No bare } \\
\text { fallow }\end{array}$ & $\begin{array}{c}\text { 2) Rotary spade } \\
\text { harrow+ } \\
\text { KF-cultivator }\end{array}$ & 3) KF-cultivator & $\begin{array}{l}\text { 4) Tined } \\
\text { cultivator }\end{array}$ & $\begin{array}{l}\text { 5) Rotary spade } \\
\text { harrow }\end{array}$ & $\begin{array}{l}\text { 6) Frequent } \\
\text { mowing }\end{array}$ \\
\hline & First silage was & harvested 20 June & & & & \\
\hline & & \multicolumn{5}{|c|}{ Mowing to $5 \mathrm{~cm}$ stubble 18 July } \\
\hline & $\begin{array}{l}\text { Second silage } \\
\text { was harvested } \\
14 \text { Aug }\end{array}$ & $\begin{array}{l}\text { Spade harrow } \\
20 \text { July } \\
\text { KF-cultivator } \\
1 \text { Aug, } 17 \text { Aug } \\
\text { and } 29 \text { Aug } \\
\text { (3 times) }\end{array}$ & $\begin{array}{l}\text { KF-cultivator } \\
19 \text { July, } 1 \text { Aug, } 17 \\
\text { Aug and } 29 \text { Aug } \\
\text { (4 times) }\end{array}$ & $\begin{array}{l}\text { Tined cultivator } \\
\text { with narrow } \\
\text { blades } 19 \text { July, } \\
1 \text { Aug, } 17 \text { Aug } \\
\text { and } 29 \text { Aug } \\
\text { (4 times) }\end{array}$ & $\begin{array}{l}\text { Spade harrow } \\
19 \text { July, } 1 \text { Aug, } 17 \\
\text { Aug and } 29 \text { Aug } \\
\text { (8 times)* }\end{array}$ & $\begin{array}{l}\text { Not } \\
\text { included } \\
2012\end{array}$ \\
\hline \multirow{5}{*}{ Spring 2013} & & $\begin{array}{l}\text { KF-cultivator } \\
1 \text { time, } 21 \text { May }\end{array}$ & \multicolumn{3}{|l|}{$\begin{array}{l}\text { KF-cultivator } \\
1 \text { time, } 21 \text { May }\end{array}$} & \\
\hline & \multicolumn{6}{|c|}{ Ploughing the whole experiment at the depth of $23 \mathrm{~cm}, 27$ May } \\
\hline & \multicolumn{6}{|c|}{ Seedbed harrowing 29-30 May } \\
\hline & \multicolumn{6}{|c|}{ Beef cattle slurry 18 ton ha ${ }^{-1}$ ( $40 \mathrm{~kg}$ soluble $\mathrm{N} \mathrm{ha}^{-1}$ ) and harrowing, 29 May } \\
\hline & \multicolumn{6}{|c|}{ Sowing spring barley (var. "Brage") 500 seeds m², 30 May } \\
\hline Autumn 2013 & \multicolumn{6}{|c|}{$\begin{array}{l}\text { Weed samples } 20 \text { Aug } \\
\text { Barley harvest } 10 \text { Sep }\end{array}$} \\
\hline
\end{tabular}

*Poor tillage performance of the spade harrow was compensated by driving the plots twice during same day.

Table 3. Treatments and other farming operations in experiment 2 in 2013-2014

\begin{tabular}{|c|c|c|c|c|c|c|}
\hline \multicolumn{7}{|c|}{ Treatments } \\
\hline & $\begin{array}{l}\text { 1) No bare } \\
\text { fallow }\end{array}$ & $\begin{array}{l}\text { 2) Rotary spade } \\
\text { harrow + KF- } \\
\text { cultivator }\end{array}$ & $\begin{array}{l}\text { 3) KF- } \\
\text { cultivator }\end{array}$ & 4) Tined cultivator & $\begin{array}{l}\text { 5) Rotary spade } \\
\text { harrow }\end{array}$ & $\begin{array}{l}\text { 6) Frequent } \\
\text { mowing }\end{array}$ \\
\hline & \multicolumn{6}{|c|}{ First silage was harvested 13 June } \\
\hline Summer 2013 & $\begin{array}{l}\text { Second } \\
\text { silage was } \\
\text { harvested } \\
7 \text { Aug }\end{array}$ & $\begin{array}{l}\text { Spade harrow } \\
18 \text { June } \\
\text { KF-cultivator } \\
4 \text { July, } 23 \text { July, } 5 \\
\text { Aug, } 22 \text { Aug and } \\
4 \text { Oct (5 times) }\end{array}$ & $\begin{array}{l}\text { KF-cultivator } \\
18 \text { June, } 4 \\
\text { July, } 23 \text { July, } \\
5 \text { Aug, } 22 \\
\text { Aug and } 4 \\
\text { Oct ( } 6 \text { times) }\end{array}$ & $\begin{array}{l}\text { Tined cultivator } \\
\text { with goosefoot } \\
\text { blades } \\
4 \text { July, } 24 \text { July, } 5 \\
\text { Aug, } 22 \text { Aug, } 30 \\
\text { Aug and } 4 \text { Oct } \\
\text { (6 times) }\end{array}$ & $\begin{array}{l}\text { Spade harrow } \\
18 \text { June, } 4 \text { July, } \\
23 \text { July, } 5 \text { Aug, } \\
22 \text { Aug and } 4 \\
\text { Oct (12 times)* }\end{array}$ & $\begin{array}{l}\text { Mowing with } \\
\text { rotary crusher } \\
1 \text { July, } 23 \text { July, } \\
31 \text { July, } 7 \text { Aug, } \\
21 \text { Aug, } 3 \text { Sep } \\
\text { and } 7 \text { Oct } \\
\text { (7 times) }\end{array}$ \\
\hline \multirow{4}{*}{ Spring 2014} & \multicolumn{6}{|c|}{ Ploughing the whole experiment at the depth of $23 \mathrm{~cm}, 26$ May } \\
\hline & \multicolumn{6}{|c|}{ Seedbed harrowing, 2-3 June } \\
\hline & \multicolumn{6}{|c|}{ Beef cattle slurry 17 ton ha ${ }^{-1}$ ( $34 \mathrm{~kg}$ soluble $\mathrm{N} \mathrm{ha}^{-1}$ ) and harrowing, 2 June } \\
\hline & \multicolumn{6}{|c|}{ Sowing spring barley (var. "Einar") 500 seeds $\mathrm{m}^{-2}, 3$ June } \\
\hline Autumn 2014 & \multicolumn{6}{|c|}{$\begin{array}{l}\text { Weed samples, } 25 \text { Aug } \\
\text { Barley harvest, } 1 \text { Sep }\end{array}$} \\
\hline
\end{tabular}

$*=$ Poor tillage performance of the spade harrow was compensated by driving the plots twice during same day. 
Frequent mowing of ley (treatment 6) was included in the experiment in 2013, as some farmers claimed to be able to decrease the amount of $E$. repens that way. This was also noted by Ringselle et al. (2015a). The ley was mown 7 times during July-October, each time the grass reached a height of 10-15 cm. The mowing was conducted using a McConnel horizontal rotary mower and the target stubble height was under $5 \mathrm{~cm}$ (Suppl. Fig. 9). The driving speeds, PTO-speeds and working depths are presented in Table 4.

Table 4. Machinery adjustments in experiment 2

\begin{tabular}{lccc}
\hline & Driving speed & PTO-speed* & Working depths \\
\hline KF-cultivator & $4-5 \mathrm{~km} \mathrm{~h}^{-1}$ & $540-600 \mathrm{~min}^{-1}$ & $10-12 \mathrm{~cm}$ \\
SMS-cultivator & $8-10 \mathrm{~km} \mathrm{~h}^{-1}$ & - & $10-12 \mathrm{~cm}$ \\
McConnel-mower & $6-8 \mathrm{~km} \mathrm{~h}^{-1}$ & $540 \mathrm{~min}^{-1}$ & $+2-5 \mathrm{~cm}$ \\
Wärtsila-rotary spade harrow & $12-14 \mathrm{~km} \mathrm{~h}^{-1}$ & - & $2-6 \mathrm{~cm}$ \\
\hline
\end{tabular}

The size of experimental plots was $6 \times 20 \mathrm{~m}$. The amount of $E$. repens shoots was not counted at the beginning of the experiments, since it would have been very difficult in growing ley. The experimental areas were placed in locations where it could be assumed that $E$. repens was evenly distributed. The plant samples were taken and analysed in a way similar to experiment 1 in 2013 (scissors, $2 \times 0.25 \mathrm{~m}^{2}$ frame).

\section{The experimental design and statistical models in experiments 1 and 2}

The experimental design was a randomized complete block with four replicates and each experimental year was treated as individual, since there were significant interactions between years and treatments. The statistical model was

$$
\chi i j=\mu+\alpha i+b j+\varepsilon i j,
$$

where $\mu$ is the constant, $\alpha i$ is the treatment factor, $b j$ is the block factor and $\varepsilon i j$ is the error term.

Data about $E$. repens shoot density at the beginning of experiment 1 were not used as a covariate in the statistical model, as there were no statistically significant differences in E. repens shoot density $(p=0.07)$. The weed and barley yield data were analysed by ANOVA using the PROC MIXED function of the SAS program (version EG 5.1, SAS Institute Inc., Cary, NC). Model assumptions were checked graphically from the residuals and by means of the UNIVARIATE procedure. There was no need to make transformations to data. Pairwise comparisons were performed using the Tukey-Kramer test.

\section{Weather conditions}

The growing season of 2012 was wetter and colder at Ruukki than the long-term average (Table 5). Alternatively, growing seasons 2013-2014 were slightly dryer and clearly warmer compared to the long-term average. Certainly, there were also cold periods (e.g. June 2014) and heavy rains (e.g. July 2014).

\section{Costs}

The cost calculations of using the KF-cultivator were based on the standards of the TTS-institute (Palva 2013). The price of a three-metre-wide cultivator was estimated to be 15000 EUR (VAT 0\%); lifetime 10 years; residual value 5000 EUR; operating time $100 \mathrm{~h}_{\text {year }}^{-1}$ and interest $5 \%$; the price for tractor work including the driver was assumed to be 52 EUR $^{-1}$.

\section{Results}

\section{Experiment 1}

At the beginning of the experiment the abundance of $E$. repens was on average 283 shoots $\mathrm{m}^{2}$. The lowest value was 104 shoots $\mathrm{m}^{-2}$ and the highest 400 shoots $\mathrm{m}^{-2}$ ( $\mathrm{N}=48$ counting plots). The quantity of $E$. repens can be considered very high and sufficient for the experimental efforts.

None of the methods applied in the experiment decreased the amount of E. repens remarkably (Fig. 1). In the first year there were no statistically significant differences between the treatments. The amounts of $E$. repens was 130-200 g DM m² before the barley harvest. According to our observations, a high amount of E. repens predisposed cereal to lodging and substantially hampered combining. 
Table 5. Weather conditions at Ruukki during 2012-2014 and long-term averages 1981-2010 (Finnish Meteorological Institute)

\begin{tabular}{|c|c|c|c|c|c|c|c|c|}
\hline \multirow[t]{2}{*}{ Month } & \multicolumn{4}{|c|}{ Rainfall, mm } & \multicolumn{4}{|c|}{ Growing degree-days, ${ }^{\circ} \mathrm{C}$} \\
\hline & 2012 & 2013 & 2014 & $1981-2010$ & 2012 & 2013 & 2014 & 1981-2010 \\
\hline May & 64 & 27 & 46 & 42 & 96 & 213 & 137 & 95 \\
\hline June & 76 & 88 & 31 & 50 & 204 & 336 & 199 & 244 \\
\hline July & 58 & 60 & 115 & 77 & 291 & 310 & 424 & 338 \\
\hline August & 83 & 47 & 44 & 71 & 246 & 291 & 310 & 263 \\
\hline September & 52 & 31 & 18 & 50 & 121 & 175 & 152 & 113 \\
\hline Sum & 332 & 255 & 254 & 289 & 958 & 1324 & 1221 & 1052 \\
\hline
\end{tabular}

In the second year (Fig. 1), the autumn ploughing was slightly better than spring ploughing with skimmers or shallow tillage (treatment 4). The same E. repens level as in autumn ploughing was achieved with the KF-cultivator without (5) or with autumn ploughing (6). Trashboards or skimmers did not improve control efficacy against E. repens, which was surprising. The implements did typically bury stubble and weeds well, but in some cases E. repens rhizomes and shoots were left above the soil surface. Evidently, peat soil was very soft and therefore the buried pieces of $E$. repens grew very quickly through the furrows. On heavier soils the results could be more favourable for such implements.

Other weeds found were mainly annuals in both years, but their amounts were low $\left(<40 \mathrm{~g} \mathrm{DM} \mathrm{m}^{-2}\right)$ and there were no statistically significant differences between the treatments.

The barley yields were $2500-3000 \mathrm{~kg} \mathrm{ha}^{-1}$ in the ploughed treatments (Fig. 2). Already in the first year the treatments without ploughing ( 4 \& 5) produced significantly lower yields than spring ploughed treatments ( 1 \& 2 ). In the second year all treatments with ploughing (1-3 \& 6) produced significantly higher yield than treatments without ploughing $(4 \& 5)$. The reason for this could not be due only to a high infestation of $E$. repens, since in KFtreatment 5 the amount of E. repens was one of the lowest in the experiment (Fig. 1).

In all likelihood, the treatments without ploughing suffered at least in 2013 from the soil being too compacted. The yield difference in 2013 between treatments 5 and 6 may indicate this: treatment 6 had been ploughed in autumn 2012 and its barley yield was clearly better than in treatment 5, which was not ploughed. Otherwise, treatments 5 and 6 were conducted similarly in spring 2013. Ploughing in autumn or spring did not affect the barley yields (Fig. 2). Barley hectolitre weights were $60-63 \mathrm{~kg} \mathrm{hl}^{-1}$ and there were no significant differences between the treatments in either year.

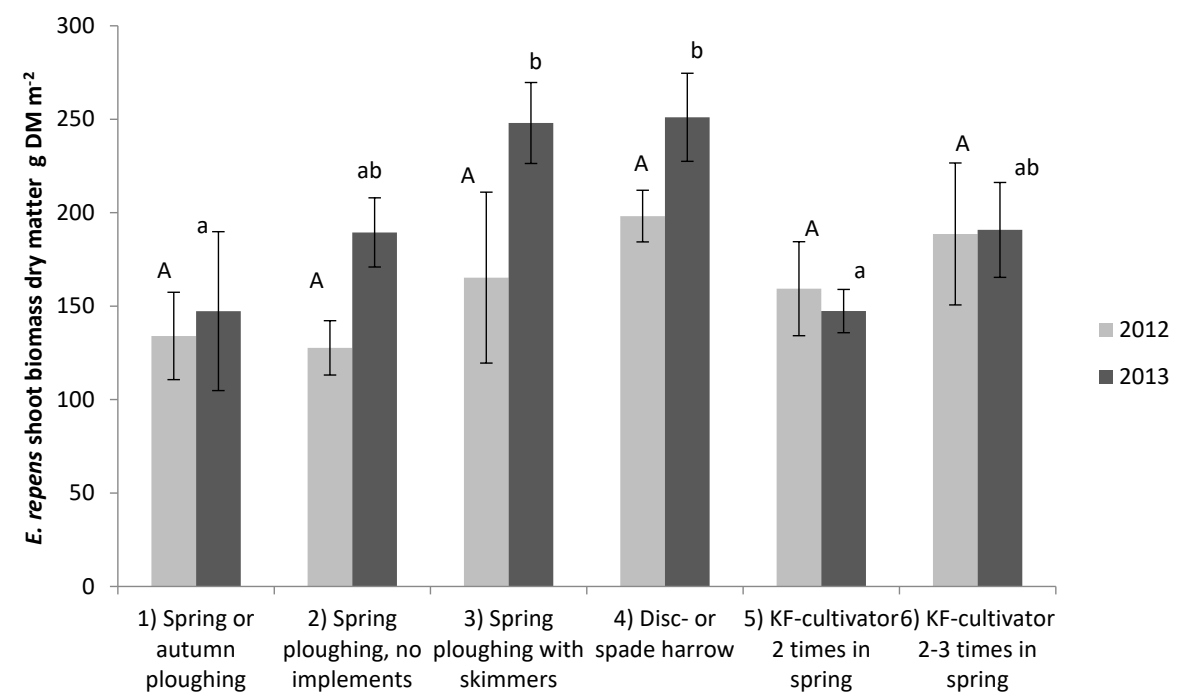

Fig. 1. Average dry matter of $E$. repens shoot biomass in autumn in experiment $1\left(\mathrm{~g} \mathrm{DM} \mathrm{m}^{-2}\right)$. The experiment was conducted in the same fixed place during 2012-2013. Standard deviations of the treatments are marked with bars $(n=4)$. The treatments with different letters were significantly different at $95 \%$ confidence. Note: The significance can be compared only within years, not between years. 


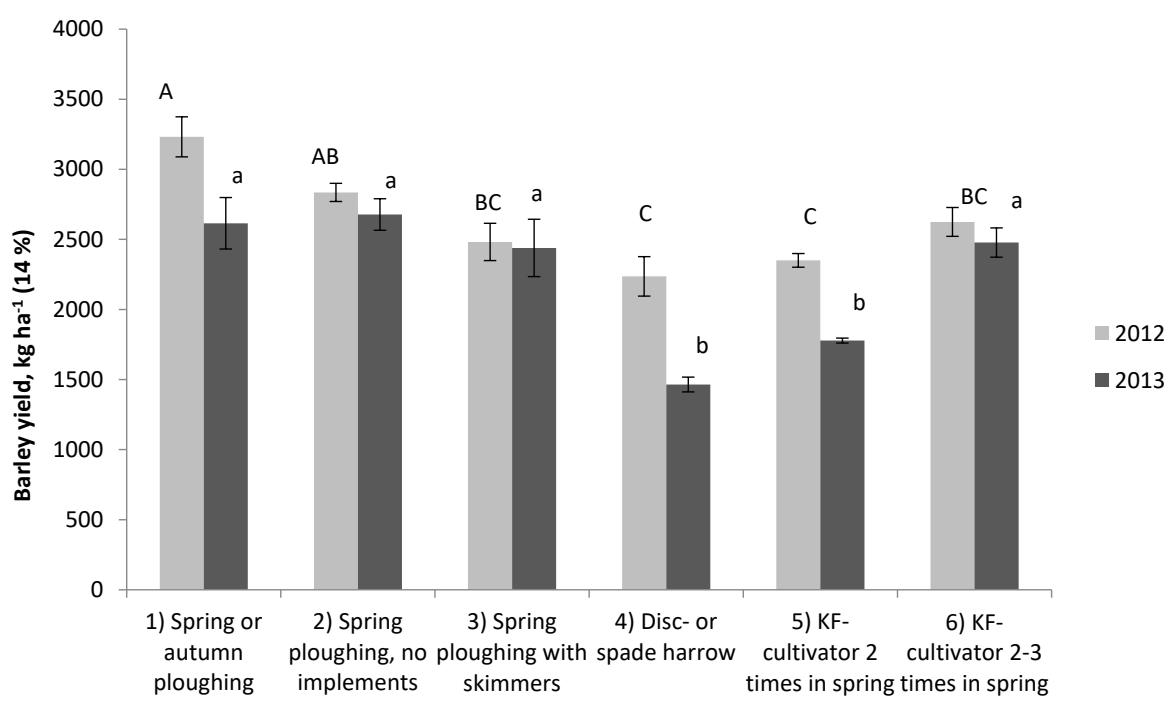

Fig. 2. Average barley yields $\left(\mathrm{kg} \mathrm{ha}^{-1}\right)$ in experiment 1 (moisture content $14 \%$ ). The experiment was conducted in the same fixed place during 2012-2013. Standard deviations of the treatments are marked with bars $(n=4)$. The treatments with different letters were significantly different at $95 \%$ confidence. Note: The significance can be compared only within years, not between years.

\section{Experiment 2}

The treatment without bare fallow (1) had a substantial occurrence of E. repens before barley harvest (Fig. 3). The infestation of $E$. repens was even higher than in experiment 1, although all plots were ploughed in spring in experiment 2. Bare fallow with the KF-cultivator decreased E. repens dry weight $86-98 \%$ compared to treatment 1 (No bare fallow). The soil was soft, thus the beginning of tillage was easy with the KF-cultivator and the first pass with the rotary spade harrow seemed to be unnecessary. In the second year, an exceptionally high amount of $E$. repens was recorded in one sample in treatment 3 . If this observation was assumed to be erroneous, the averages of treatments 2 and 3 would be very close to each other.

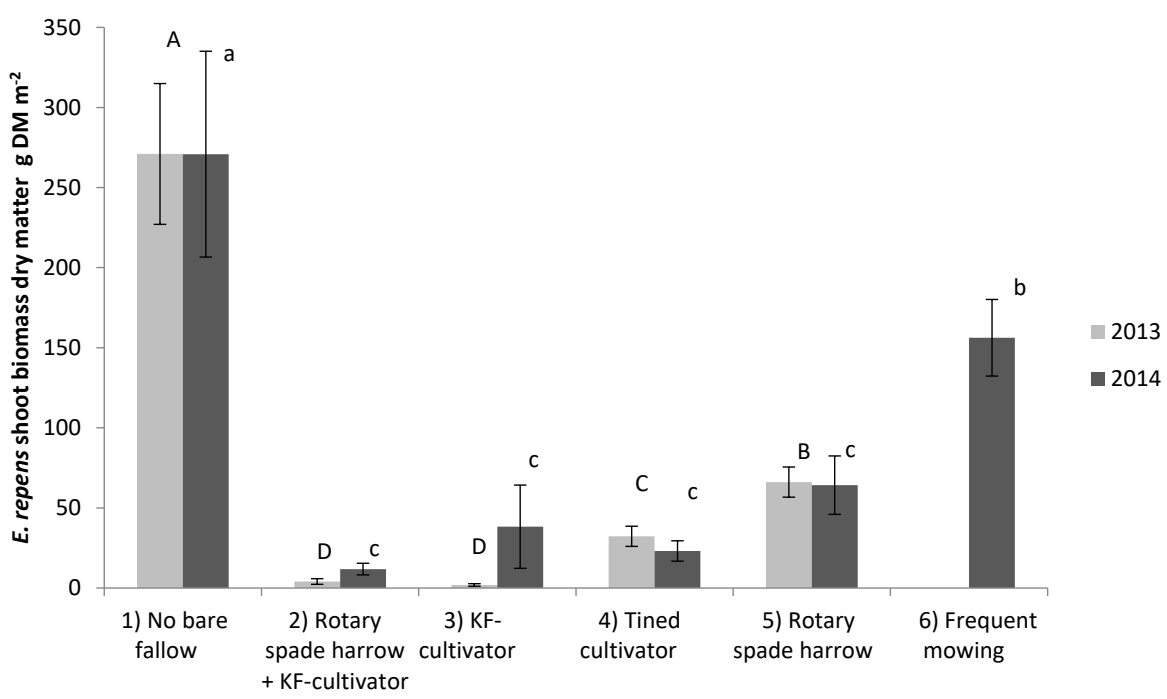

Fig. 3. Average dry matter of $E$. repens shoot biomass in autumn in experiment $2\left(\mathrm{~g} \mathrm{DM} \mathrm{m}^{-2}\right)$. The location of the experiment was changed between 2013 and 2014. Standard deviations of the treatments are marked with bars $(n=4)$. The treatments with different letters were significantly different at $95 \%$ confidence. Note: The significance can be compared only within of years, not between years.

Bare fallowing with a tined cultivator (4) decreased the amount of E. repens by $90 \%$ compared to the treatment without bare fallow (1), which is also a good result. The tined cultivator with narrow blades (2012) left the surface of the cultivated ley more even than the cultivator with goosefoot blades (2013). Rugged peat soil made driving uncomfortable during subsequent passes and consequently the working depth varied. 
The rotary spade harrow (5) decreased the amount of E. repens by $75 \%$ compared to treatment 1 (Fig. 3 ). This is a satisfying result given that the harrow could not break the surface of the ley properly, although two passes were always made during the same day. This led to a high number of passes with 8-12 per summer. It is clear that the high amount of surviving $E$. repens $\left(65 \mathrm{~g} \mathrm{DM} \mathrm{m}^{-2}\right)$ will increase quickly during the coming years. In treatment 6 , frequent mowing was not very effective against $E$. repens despite numerous passes. It was only able to destroy less than half of $E$. repens shoot biomass compared to the biomass growing in treatment 1 . Despite a satisfactory mowing quality, the repeated mowing had a mediocre effect on E. repens shoot biomass.

Treatments 2-4 effectively decreased $E$. repens, but annual weeds occupied the free growing space. In both years there were about $30 \mathrm{~g} \mathrm{DM} \mathrm{m}^{-2}$ of annual weeds in treatment 1 . The amounts of annual weeds in treatments $2-4$ ranged from 70-90 $\mathrm{g} \mathrm{DM} \mathrm{m}^{-2}$ in 2013 and 115-145 $\mathrm{g} \mathrm{DM} \mathrm{m}^{-2}$ in 2014. There were statistically significant differences between treatments 1 and 5 in 2013 and between treatments 1 and 3 \& 4 in 2014. The annual weeds were mainly Persicaria lapathifolia and Chenopodium album. Especially in 2014, the amount of annual weeds was so high that barley was predisposed to lodging and the yields decreased due to competition. Weed harrowing at the shooting stage of barley would have been necessary, but a weed harrow was not available.

Barley yields were satisfying from an organic farming perspective, especially in 2013, which after using the KFcultivator showed yields of about $3700 \mathrm{~kg} \mathrm{ha}^{-1}$ (Fig. 4). The treatment without bare fallow (1) produced a 1000 $\mathrm{kg} \mathrm{ha}^{-1}$ lower yield. In 2014, the emergence of annual weeds and crop lodging after thunder storms decreased barley yields. In treatments $2-5$, barley yields were about $2500 \mathrm{~kg} \mathrm{ha}^{-1}$ and in treatment 1 again $1000 \mathrm{~kg} \mathrm{ha}^{-1}$ lower. After frequent mowing (6) barley yield was $2200 \mathrm{~kg} \mathrm{ha}^{-1}$. Barley hectolitre weights were 59-63 $\mathrm{kg} \mathrm{hl}^{-1}$ and there were no significant differences between the treatments in either year.

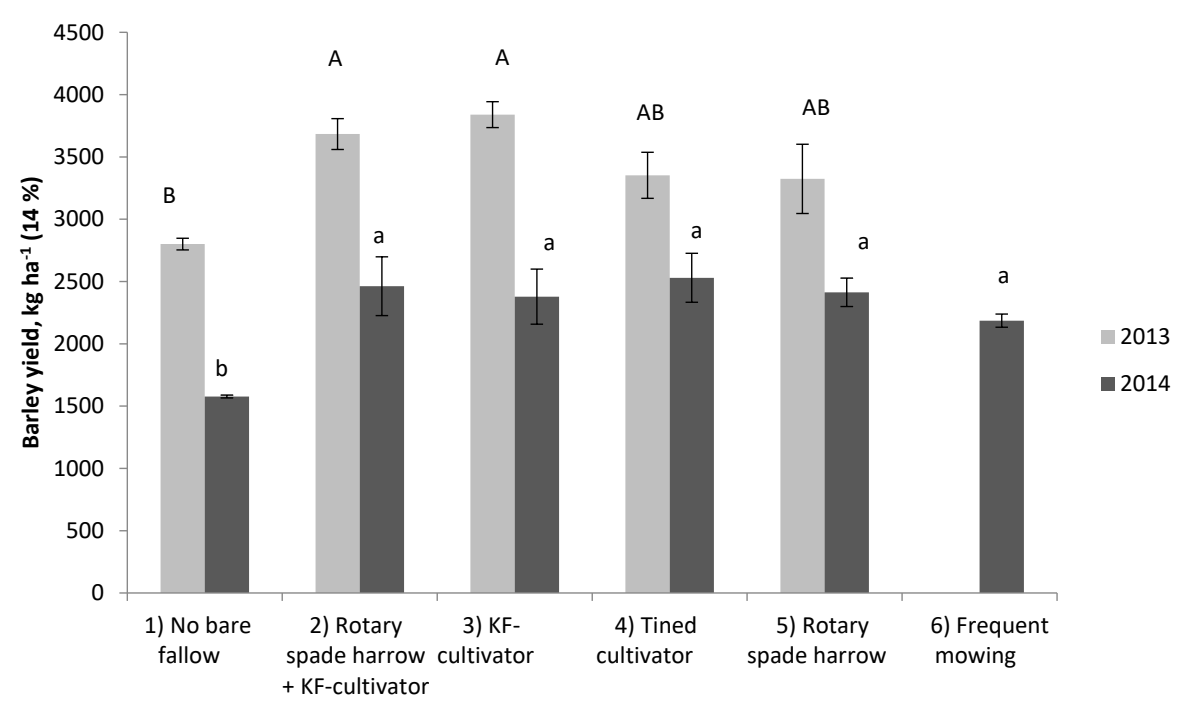

Fig. 4. Average barley yields $\left(\mathrm{kg} \mathrm{ha}^{-1}\right)$ in experiment 2 (moisture content $\left.14 \%\right)$. The location of the experiment was changed yearly. Standard deviations of the treatments are marked with bars $(n=4)$. The treatments with different letters were significantly different at $95 \%$ confidence. Note: The significance can be compared only within years, not between years.

\section{Discussion}

\section{Experiment 1}

A brief fallow in spring before cereal sowing was not sufficiently effective against $E$. repens. Peat soil is probably one of the most challenging soils from the point of view of mechanical weed control. Peat soil is moist and soft, thus the rhizomes and roots of perennial weeds are able to grow easily and rapidly.

After use of the KF-cultivator, the rhizomes of E. repens dried out and clearly turned brown, but obviously did not die completely. As the beginning of May in both years was rainy, it was only possible to start the cultivations quite late and therefore the fallowing time was only two weeks. This was clearly not a long enough period for an organic and moist soil. If there would have been stubble cultivation(s) already in previous autumn, the effect of spring treatments may have been improved, as seen in Jacobsson's (2006) experiments in Sweden. 
If the situation is as in experiment 1 (high proliferation of $E$. repens in cereal stubble), better weed control results could probably be achieved by fallowing effectively from May through to the end of June. After that a green manure crop could be sown to suppress surviving weeds and to produce nitrogen for next year's crop (Thomsen et al. 2015).

Autumn ploughing was slightly better than spring ploughing, though not significantly. Unfortunately, autumn ploughing could be performed only in 2013 due to practical reasons. In agreement with our study, only a little difference in ploughing effects have been found in both light soils (Jacobsson 2006) and clay soils (Thomsen et al. 2015). As we only performed autumn ploughing in one year, our conclusions need to be tempered.

Thomsen et al. (2015) achieved good results against E. repens and S. arvensis already with three weeks of bare fallow in spring before green manure sowing (two-disc harrowing). The amount of $E$. repens in clay soil was less than $20 \mathrm{~g} \mathrm{DM} \mathrm{m}^{-2}$ in the untreated control in the subsequent year, which was much less than in our experiment (about $140 \mathrm{~g} \mathrm{DM} \mathrm{m}^{-2}$ ). The initial weed situation and soil type were therefore more challenging in our study compared to Thomsen et al.'s (2015) study.

Ploughing in autumn or spring did not affect barley yields. Similar results were achieved in three years of conventional farming experiments in peat and sandy soils (Lötjönen \& Isolahti 2010). Jacobsson (2006) likewise did not notice yield difference in light soils, but in heavier soils, spring ploughing produced a higher yield than autumn ploughing in one experimental year. However, spring ploughing can decrease seed germination in heavy soils if the weather is dry during spring. In our experiment, ploughing seemed to be necessary together with brief fallow to control E. repens and to improve cereal yield.

\section{Experiment 2}

The KF-cultivator very effectively reduced $E$. repens in experiment 2, even though the weather was rainy and cool in summer 2012. There were not many cultivation days that were dry enough and destruction of $E$. repens was probably more due to the exhaustion of rhizome food reserves than from drying out. There was one pass with the KF-cultivator in spring 2013 before ploughing, but not in spring 2014. This could explain why the effect of the KF-cultivator was not as good in 2014. Also ordinary cultivators had a beneficial effect, although after their use the field surface was left uneven, which made the following passes unpleasant, which can decrease the driving speed and thus working capacity.

In 2013, treatments were started about one month earlier than in 2012, which led to a higher number of passes. According to the results, it may not be sensible to increase the number of passes from the number carried out in 2012. Thus, four passes with the KF-cultivator in late summer and one the next spring seemed to be enough in these conditions taking into account the control efficacy and the costs. However, determining the optimum number of passes requires further research.

Midsummer fallows have been studied previously in both Denmark and Finland with significant but smaller reductions in $E$. repens than in our study. In these studies, fallow decreased the amount of $E$. repens by $50-75 \%$ compared to untreated control (Väisänen \& Kakriainen-Rouhiainen 2004, Rasmussen et al. 2014). However, in our study the fallowing period was longer, since a catch crop/winter crop was not sown in autumn as in other studies.

The largest disadvantages in carrying out ley breakage by late summer fallow are likely to be from having bare and intensively tilled soil over the winter period, resulting in evident nutrient losses. Fallow during May-June could be a better option to break old leys. On the other hand, this kind of fallow should be compared to autumn ploughed ley in terms of nutrient losses and other disadvantages. The encouraging results seen with the KF-cultivator encourage further studies on other perennial weeds, e.g. C. arvense and S. arvensis. Thus, further research is required before more detailed recommendations can be given to farmers.

\section{Costs}

The KF-cultivator has been criticized as being slow. The driving speed with the KF-cultivator can be $4-7 \mathrm{~km} \mathrm{~h}^{-1}$, and thus the capacity of a $3.0 \mathrm{~m}$ machine could be 1.1-1.3 ha $\mathrm{h}^{-1}$. The cost of one treatment would be about 60 EUR ha-1. If we assume that 6 treatments are required when old ley is broken up, the method can be considered expensive. On the other hand, if ploughing and seedbed tillage can be excluded, the costs of 6 treatments would be about 180-230 EUR ha-1. This is an acceptable cost for rigorous perennial weed control, since there is no need to repeat the treatment every year. 
Depending on crop rotation and soil type, this kind of fallow may be necessary every fifth year or more rarely in organic farming. For example, if the crop rotation is two years of cereals plus three years of ley, it is probable that effectively managed late summer fallow during the last ley year will be enough for most situations.

\section{Conclusion}

In Finland, E. repens is the most harmful weed species causing considerable economic losses in crop production. Therefore, improved management practices are welcome to enhance the control of E. repens. Mechanical control methods are of interest not only for organic production but also for conventional cropping to meet the EU requirements of integrated weed management and sustainable use of herbicides. Including a bare fallow period in the crop rotation is a costly option which should end up with the most effective and long-lasting control of E. repens.

There were marked differences in control efficacy between the control strategies (timing) and different machinery studied in our field experiments. Evidently, to achieve an effective control of E. repens, the late summer and autumn period are more feasible than any quick efforts in the spring before sowing. Kvick-Finn weed cultivator proved to control E. repens very effectively and the economic return as yield increase in the subsequent barley crop was satisfactory.

The costs of rigorous mechanical weed control are reasonable if we assume that in well designed crop rotation this kind of operation may be needed every fifth year or rarely. In conclusion, effective control of $E$. repens is achieved with proper machinery and repeated treatments at the optimal time.

\section{Acknowledgements}

Practical field work in this study was conducted by Esko Leiviskä, Jarkko Kekkonen, Timo Keränen and Osmo Keränen. BT-Agro Oy lent machinery and provided guidance on their operation. The plant samples were taken and analysed by Ruukki Research Station staff. The research was funded by Ely-Centre of North Ostrobothnia, BT-Agro Oy and MTT Agrifood Research Finland. We want to thank everyone involved in this project and the financiers for their support.

\section{References}

Aronsson, H., Ringselle, B., Andersson, L. \& Bergkvist, G. 2015. Combining mechanical control of couch grass (Elymus repens L.) with reduced tillage in early autumn and cover crops to decrease nitrogen and phosphorus leaching. Nutrient Cycling in Agroecosystems 102: 383-396.

Bond, W. \& Grundy, A.C. 2001. Non-chemical weed management in organic farming systems. Weed Research 41: $383-405$.

Brandsaeter, L. O., Thomsen, M. G., Waernhus, K. \& Fykse, H. 2012. Effects of repeated clover undersowing in spring cereals and stubble treatments in autumn on Elymus repens, Sonchus arvensis and Cirsium arvense. Crop Protection 32: 104-110.

Dock Gustavsson, A.-M. 1994. Åkertistelns reaktion på avslagning, omgrävning och konkurrens. Sveriges lantbruksuniversitet, Fakta Mark-växter Nr. 13. Uppsala. 4 p. (in Swedish).

Dock Gustavsson, A.-M. 1997. Growth and regenerative capacity of plants of Cirsium arvense. Weed Research 37: $229-236$.

Graglia, E., Melander, B. \& Jensen, R.K. 2006. Mechanical and cultural strategies to control Cirsium arvense in organic arable cropping systems. Weed Research 46: 304-312.

Håkansson, S. 1967. Experiments with Agropyron repens (L.) Beauv. I Development and growth, and the response to burial at different developmental stages. Lantbrukshögskolans annaler 33: 823-873.

Håkansson, S. 1995. Ogräs och odling på åker. Aktuellt från lantbruksuniversitetet nro 437/438 Mark-växter. Uppsala: Sveriges lantbruksuniversitet. 70 p. (in Swedish).

Jacobsson, J. 2006. Kvickrotsbekämpning genom uttorkning och köldpåverkan efter jordbearbetning. Hushållningssällskapet rapport. 52 p. Cited 15 December 2015. www.lantbrukssallskapet.fi/wp-content/uploads/kvickrotsbekampning.pdf. (in Swedish).

Kristensen, E. F., Melander, B. \& Nørremark, M. 2010. New optimized technique for mechanical control of Elymus repens. International Conference on Agricultural Engineering, Clemont Ferrand, France, 6-8 September, 2010. AgEng 2010. 8 p.

Lötjönen, T. \& Isolahti, M. 2010. Direct drilling of cereals after ley and slurry spreading. Acta Agriculturae Scandinavica. Section B-Soil and Plant Science 60: 307-319.

Melander, B. 1994. Modelling the effects of Elymus Repens (L) Gould competition on yield of cereals, peas and oilseed rape. Weed Research 34: 99-108.

Melander, B., Holst, N., Rasmussen, I.A. \& Hansen, P.K. 2012. Direct control of perennial weeds between crops - Implications for organic farming. Crop Protection 40: 36-42. 
Melander, B., Munier-Jolain, N., Charles, R., Wirth, J., Schwarz, J., van der Weide, R., Bonin, L., Jensen, P.K. \& Kudsk, P. $2013 a$. European Perspectives on the Adoption of Nonchemical Weed Management in Reduced-Tillage Systems for Arable Crops. Weed Technology 27: 231-240.

Melander, B., Norremark, M. \& Kristensen, E.F. 2013b. Combining mechanical rhizome removal and cover crops for Elytrigia repens control in organic barley systems. Weed Research 53: 461-469.

Palva, R. 2013. Konetyön kustannukset ja tilastolliset urakointihinnat. TTS:n tiedote 645. 12 p. (in Finnish).

Rasmussen, I.A., Melander, B., Askegaard, M., Kristensen, K. \& Olesen, J.E. 2014. Elytrigia repens population dynamics under different management schemes in organic cropping systems on coarse sand. European Journal of Agronomy 58: 18-27.

Riesinger, P. 2010. Agronomic challenges for organic crop husbandry. PhD thesis. Publications I 2. Department of Agricultural Sciences. University of Helsinki. 90 p.

Ringselle, B., Bergkvist, G., Aronsson, H. \& Andersson, L. 2015a. Under-sown cover crops and post-harvest mowing as measures to control Elymus repens. Weed Research 55: 309-319.

Ringselle, B., Bergkvist, G., Aronsson, H. \& Andersson, L. 2015b. Importance of timing and repetition of stubble cultivation for post-harvest control of Elymus repens. Weed Research 56: 41-49.

Salonen, J., Hyvönen, T. \& Jalli, H. 2011. Composition of weed flora in spring cereals in Finland - a fourth survey. Agricultural and Food Science 20: 245-261.

Thomsen, M.G., Mangerud, K., Riley, H. \& Brandsaeter, L.O. 2015. Method, timing and duration of bare fallow for the control of Cirsium arvense and other creeping perennials. Crop Protection 77: 31-37.

Vanhala, P., Lötjönen, T., Hurme, T. \& Salonen, J. 2006. Managing Sonchus arvensis using mechanical and cultural methods. Agricultural and Food Science 15: 444-458.

Väisänen, J. \& Kakriainen-Rouhiainen, S. 2004. Viherlannoitusnurmen muokkaustekniikalla typpeä ohralle. In: Väisänen, J., Forsman, K., Kakriainen-Rouhiainen, S., Lötjönen, T. \& Avikainen, H. (eds.). Kasvuvoimaa luomuohralle. Maa- ja elintarviketalous nro 52. Jokioinen: Maa- ja elintarviketalouden tutkimuskeskus. p. 44-55. (in Finnish). 


\section{Supplemental Figures}

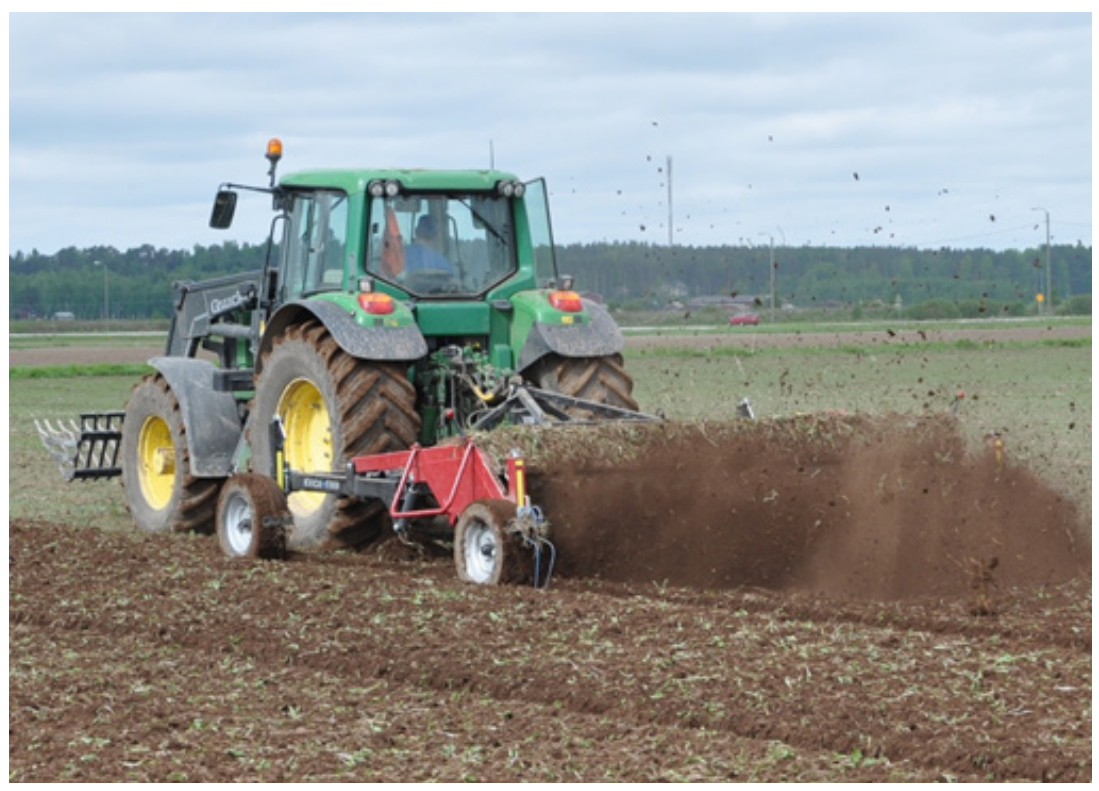

Suppl.Fig. 1. Kvick-Finn cultivator lifts the roots or rhizomes of perennial weeds to the soil surface so that sun and wind can desiccate them.

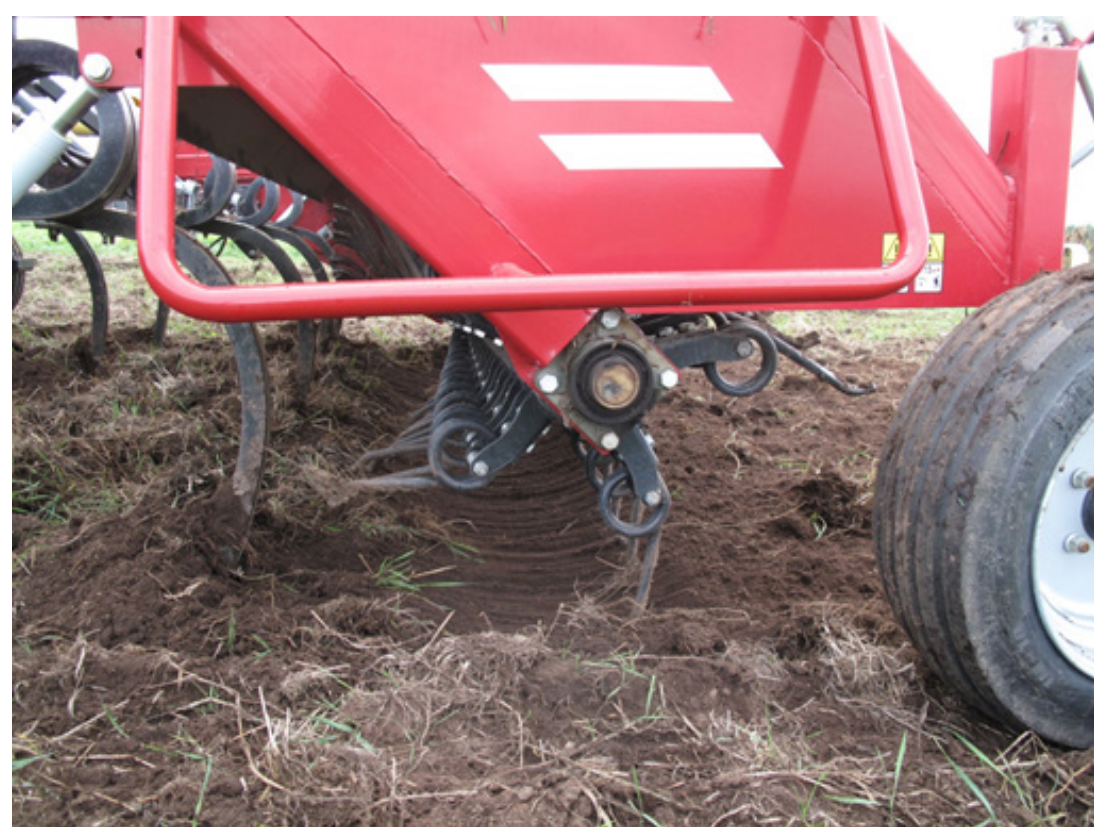

Suppl. Fig. 2. The working principle of Kvick-Finn cultivator: goosefoot tines loosen the soil and after that a PTO-driven rotor throws soil and weed roots into the air. 


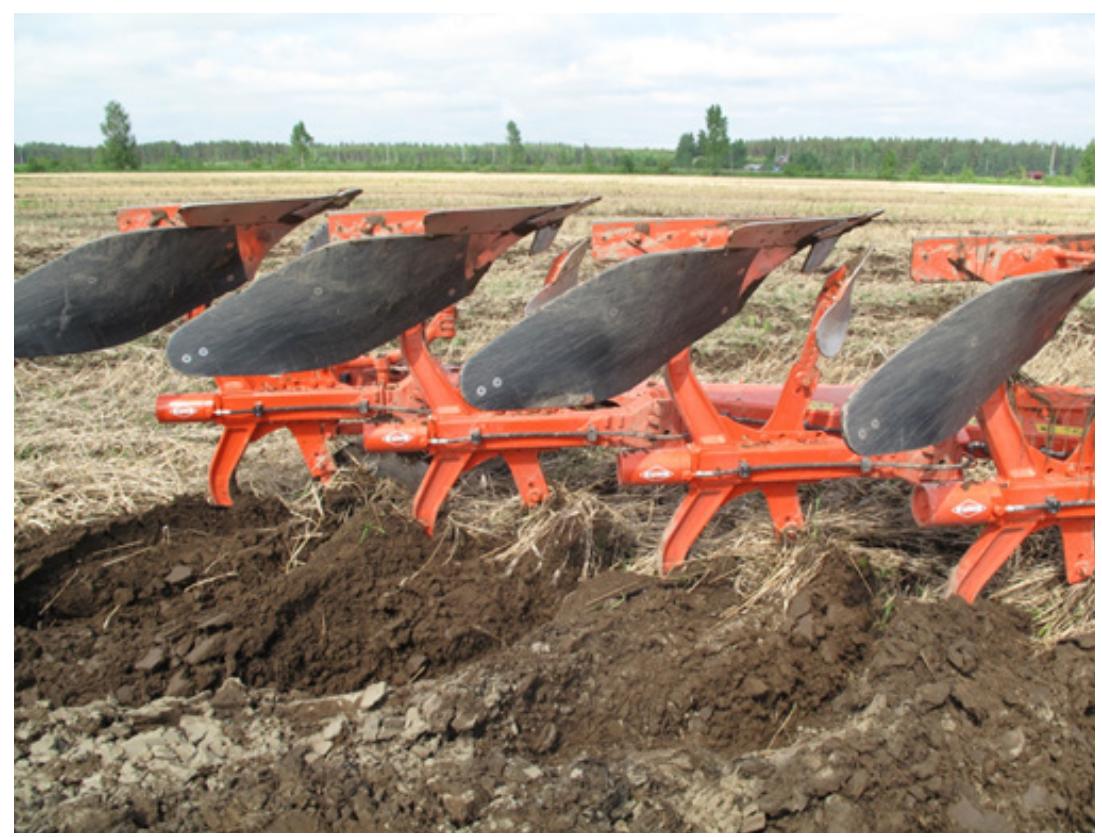

Suppl. Fig. 3. Skimmers installed on plough (between the mouldboards). This plough was used in experiment 1.

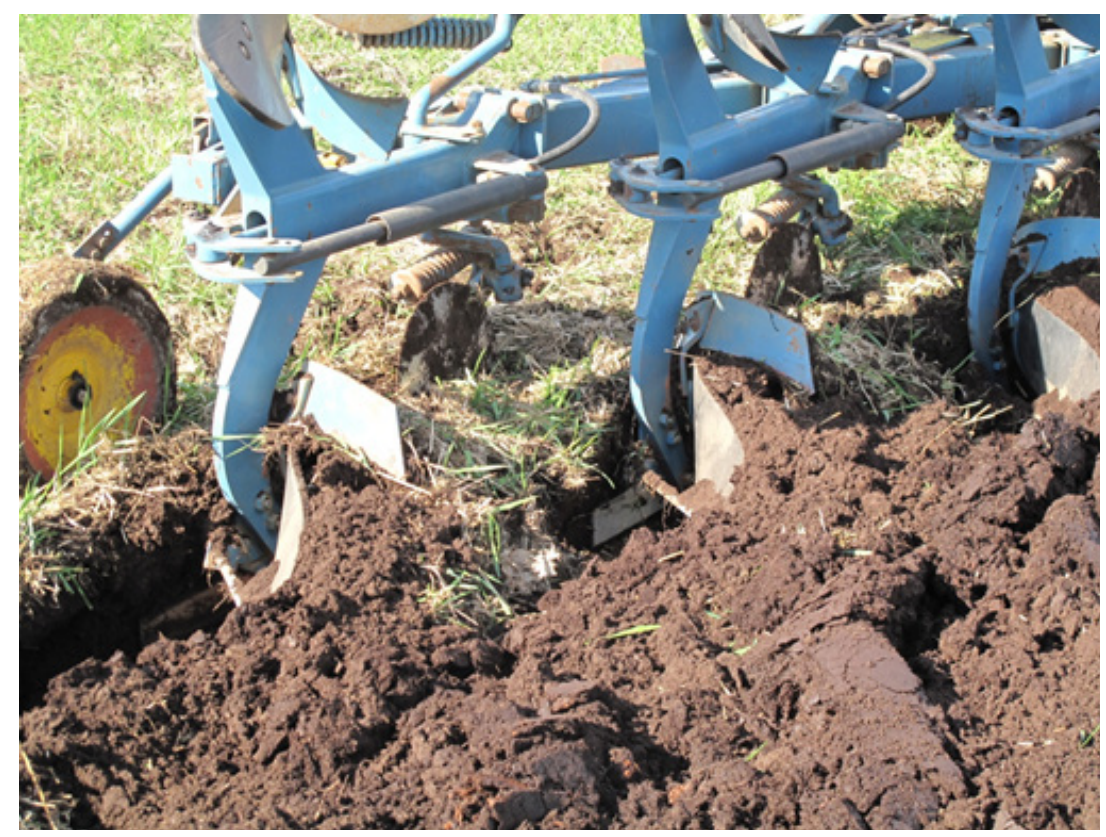

Suppl. Fig. 4. Trashboards installed on plough (above the mouldboards). This plough was used in experiment 1 and 2 . 


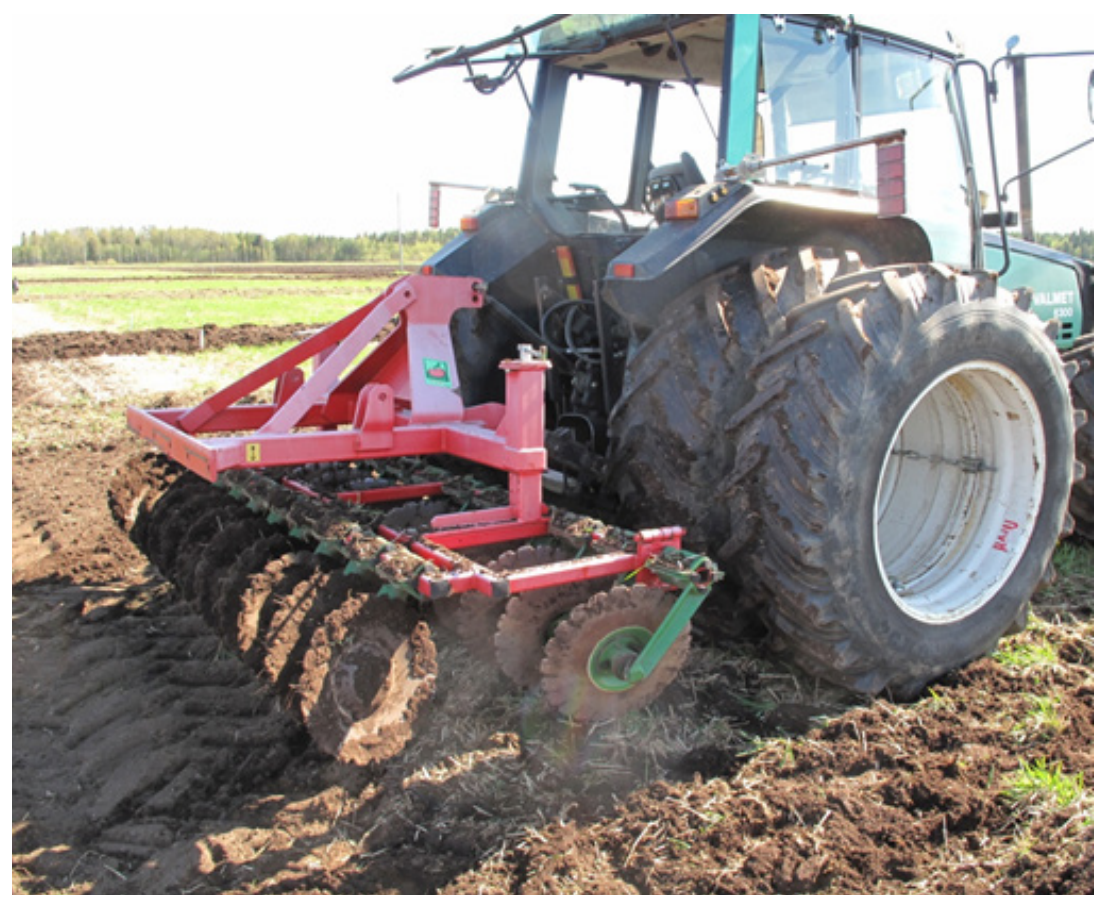

Suppl. Fig. 5. Disc harrow which was used in experiment 1 in the first year.

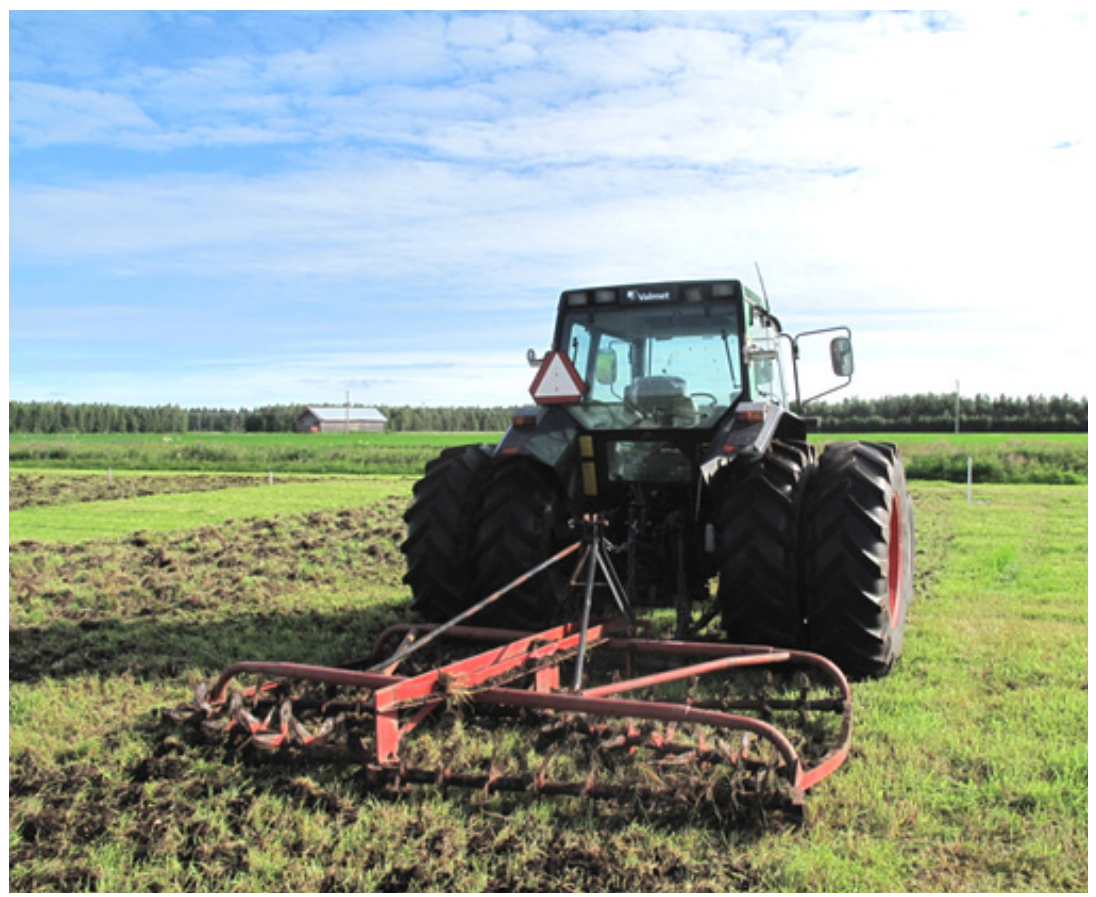

Suppl. Fig. 6. Rotary spade harrow which was used in experiment 1 in the second year and in experiment 2 in both years. 


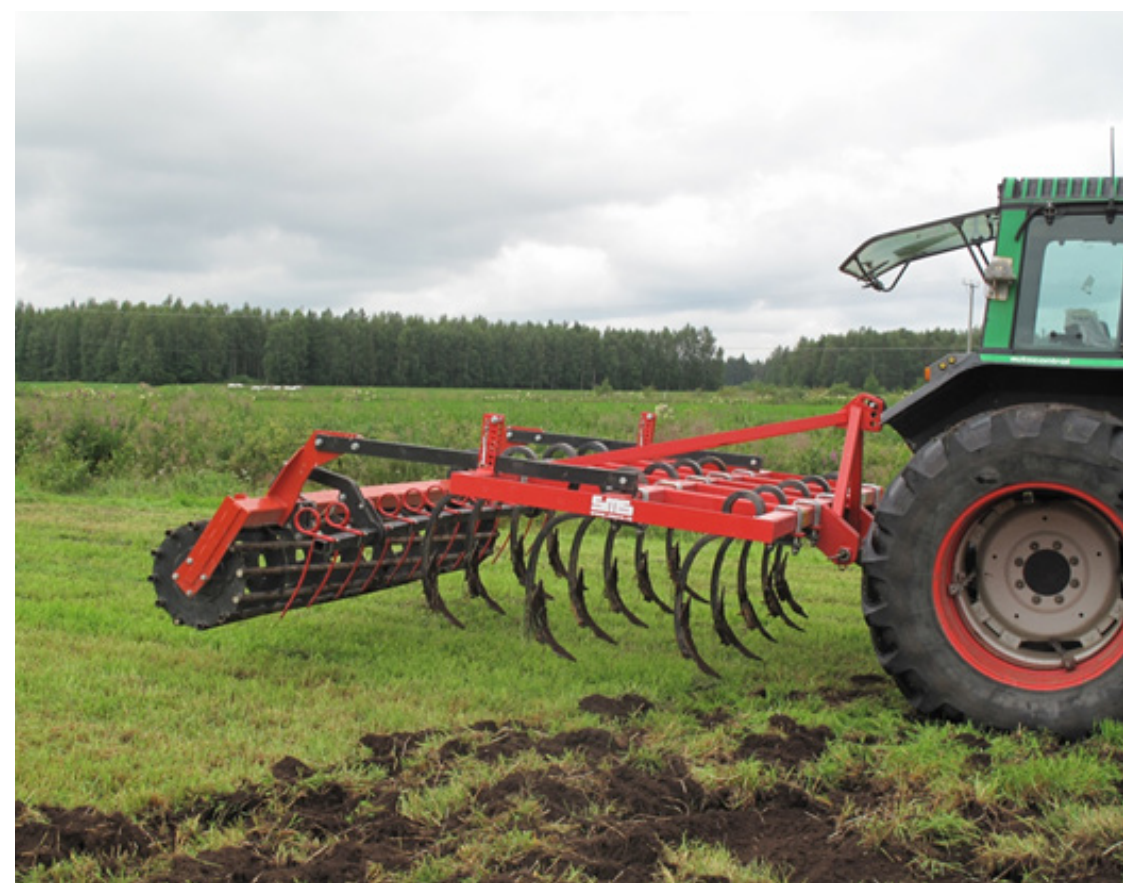

Suppl. Fig. 7. Tined cultivator with narrow blades was used in experiment 2 in the first year.

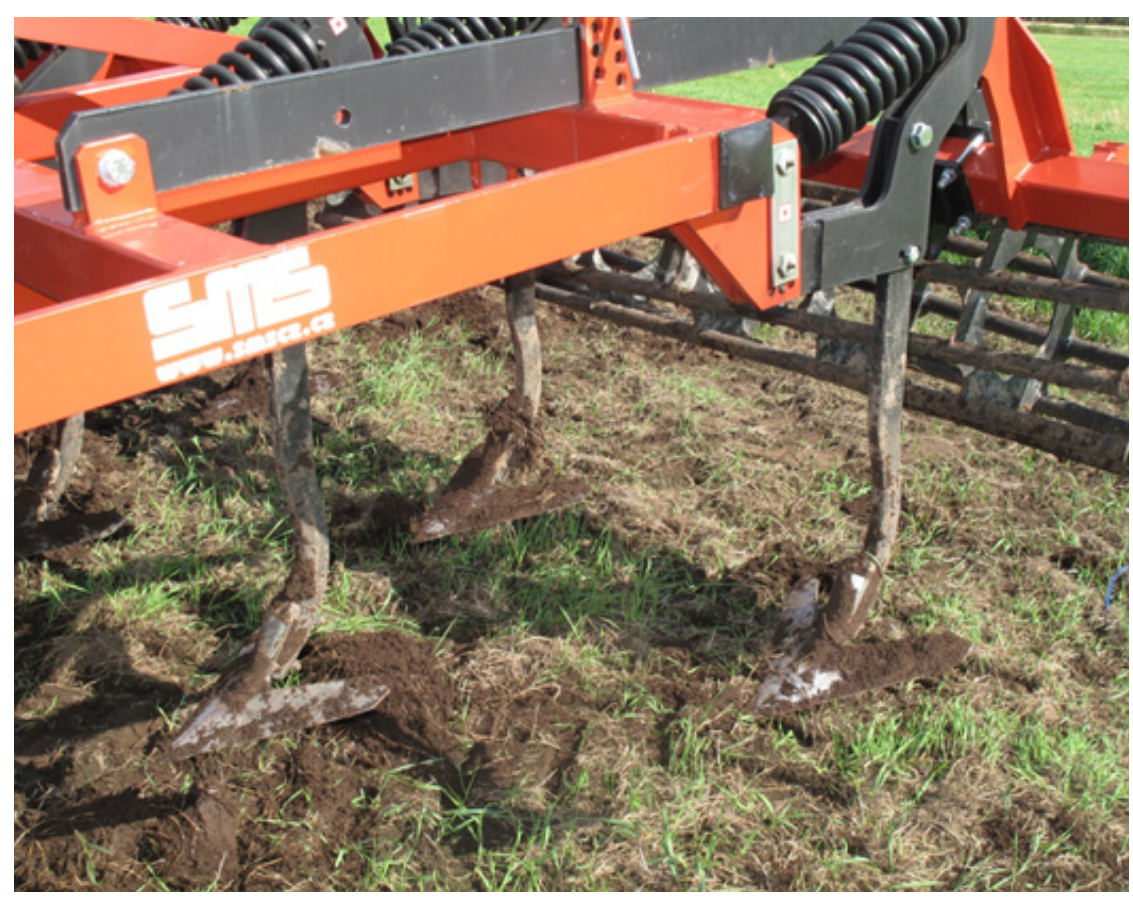

Suppl. Fig. 8. Tined cultivator with goosefoot blades was used in experiment 2 in the second year. 


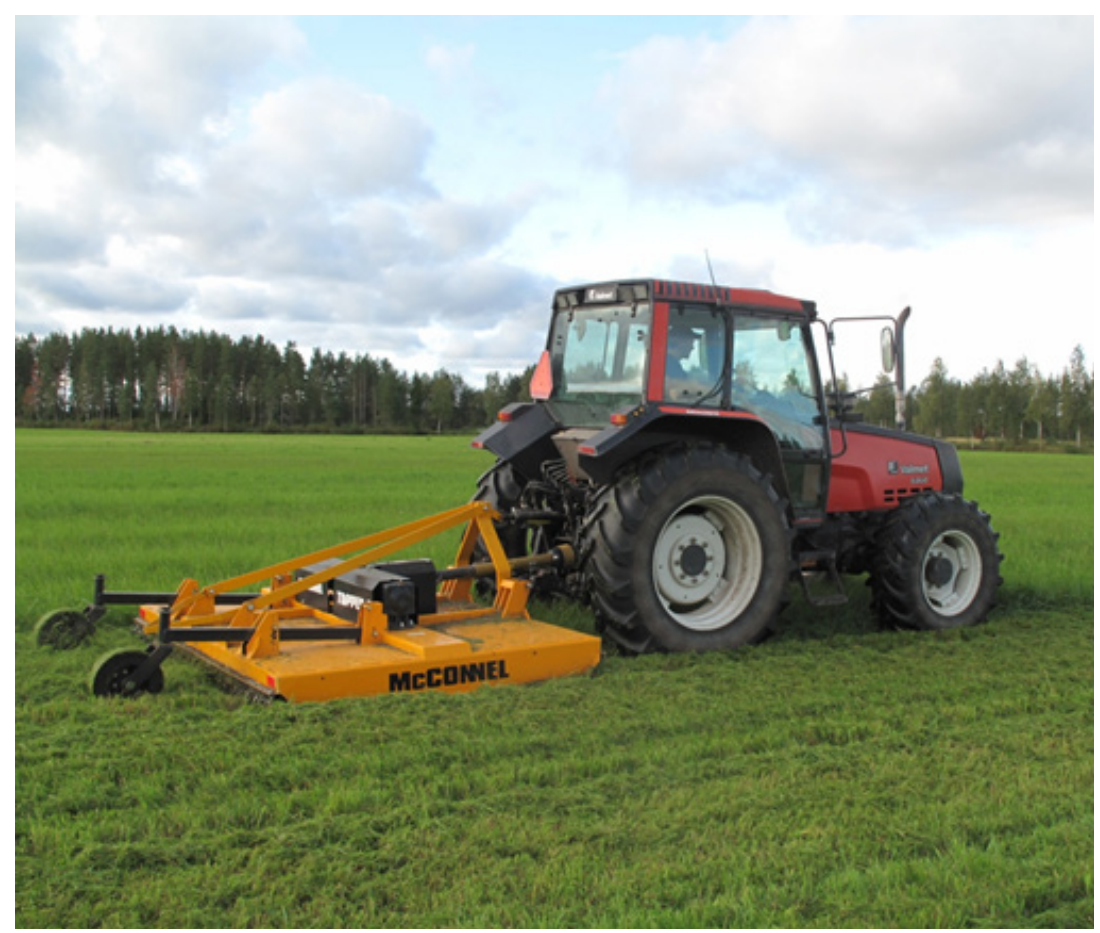

Suppl. Fig. 9. Horizontal rotary mower which was used in experiment 2 in the second year. 